\title{
IIES
}

\section{WILL THE GOVERNMENT HIT ITS CHILD POVERTY TARGET IN 2004-05?}

Mike Brewer 


\title{
Will the government hit its child poverty target in 2004-05?
}

\author{
Mike Brewer ${ }^{*}$
}

\author{
Institute for Fiscal Studies
}

This Briefing Note assesses the likelihood that the government will meet its child poverty target in 2004-05 in the light of decisions made in Pre-Budget Report (PBR) 2003. It updates the analysis presented in What Do the Child Poverty Targets Mean for the Child Tax Credit? An Update, IFS Briefing Note 41, www.ifs.org.uk/inequality/bn41.pdf, which was written before PBR 2003.

We agree with the assessment in PBR 2003 that the government should comfortably meet its target measuring incomes before housing costs (BHC). ${ }^{1}$ It also concludes that the government is on course to just hit its target measuring incomes after housing costs (AHC). However, there are uncertainties in making these forecasts, not least because the government uses a survey of around 30,000 households to estimate child poverty in a population roughly a thousand times as large. We should know for sure whether the target has been hit in Spring 2006.

\section{Child poverty targets in 2004-05}

The government wants child poverty to fall by a quarter of its level in 1998-99 by 2004-05. Measuring incomes AHC, 4.2 million children lived in households with less than $60 \%$ of median income in 1998-99; measuring incomes BHC, the figure was 3.1 million. These imply targets for 2004-05 of 3.1 million and 2.3 million children respectively.

At the time the target was announced, the government put slightly more weight on the measures based on incomes measured AHC, but it is now putting more weight on the BHC measures. This Briefing Note reports progress against both measures. Incomes are adjusted using the McClements equivalence scale,

\footnotetext{
${ }^{*}$ The author is grateful to Robert Chote for comments on an earlier draft. Support from the ESRC-funded Centre for the Microeconomic Analysis of Public Policy (grant no.

M535255111) is gratefully acknowledged. The Households Below Average Income and the Family Resources Survey data-sets are used with permission of the Department for Work and Pensions, which bears no responsibility for the views expressed here.

${ }^{1}$ See para. 5.20 of The Strength to Take the Long-Term Decisions for Britain: Seizing the Opportunities of the Global Recovery, Cm. 6042, The Stationery Office, London, 2003 (www.hm-treasury.gov.uk/pre_budget_report/prebud_pbr03/prebud_pbr03_index.cfm).
} 
although the government has announced that child poverty in the future will be tracked using the modified OECD scale. ${ }^{2}$

Table 1 shows our estimate of child poverty rates in 2004-05 before considering the increases to tax credits announced in PBR 2003. It shows that the government would have been on course to meet its child poverty target measuring incomes BHC without having to announce any changes to the tax credits in April 2004 beyond the previously-announced increase in the child element of the child tax credit in line with average earnings.

Table 1. Possible changes in child poverty, 2001-02 to 2004-05 (millions of children) before considering tax credit increases announced in PBR 2003

\begin{tabular}{|c|c|c|c|c|c|c|}
\hline Poverty line & $\begin{array}{c}(1) \\
\text { Actual } \\
\text { child } \\
\text { poverty, } \\
\text { 2001-02, } \\
\text { HBAI }\end{array}$ & $\begin{array}{c}(2) \\
\text { Change due } \\
\text { to tax and } \\
\text { benefit } \\
\text { reforms, } \\
2001-02 \text { to } \\
2004-05\end{array}$ & $\begin{array}{c}(3) \\
\text { Change due } \\
\text { to earnings } \\
\text { growth, } \\
2001-02 \text { to } \\
2004-05\end{array}$ & $\begin{array}{c}(4) \\
\text { Total change, } \\
\text { 2001-02 to } \\
2004-05\end{array}$ & $\begin{array}{c}(5) \\
\text { Estimate for } \\
2004-05 \\
\text { using HBAI } \\
\text { values for } \\
2001-02\end{array}$ & $\begin{array}{c}(6) \\
\text { Target }\end{array}$ \\
\hline $\begin{array}{l}\text { After housing } \\
\text { costs, } 60 \% \\
\text { median }\end{array}$ & 3.8 & -0.7 & +0.2 & -0.5 & 3.3 & 3.1 \\
\hline $\begin{array}{l}\text { Before housing } \\
\text { costs, } 60 \% \\
\text { median }\end{array}$ & 2.7 & -0.6 & +0.2 & -0.4 & 2.2 & 2.3 \\
\hline
\end{tabular}

Notes: Column 4 = column $2+$ column 3 ; column 5 = column $1+$ column 4 . Column 2 assumes that the child element of the child tax credit rises in line with earnings growth in April 2004, that the thresholds and family premium are frozen and that all other credits rise with inflation. Numbers are rounded to the nearest 100,000, as is the custom in HBAI, but this should not be interpreted as a measure of accuracy. Changes are based on unrounded numbers, and numbers may not sum due to rounding. Column 3 uses actual growth in average earnings between April 2001 and April 2003, and an assumed annual growth of 1\% between April 2003 and April 2004.

Source: Author's calculations from IFS tax and benefit model, TAXBEN, using 2001-02 Family Resources Survey, except column 1, which is from Department for Work and Pensions, Households Below Average Income 1994/5 to 2001/02, CDS, Leeds, 2003 (HBAI).

Table 1 reflects the government's Budget 2003 forecasting assumption that the tax credit thresholds and family element of the child tax credit would be frozen at their 2003 values. We estimate that, compared with an indexed base, freezing the tax credit thresholds and the family element of the child tax credit increases child poverty in 2004-05 by around 25,000.

\footnotetext{
${ }^{2}$ See Department for Work and Pensions, Measuring Child Poverty, London, 2003.
} 


\title{
The changes to tax credits announced in PBR 2003
}

PBR 2003 contained two key announcements about the generosity of child tax credit and working tax credit from April 2004:

- The per-child element of the child tax credit would rise by $£ 180$ a year (roughly £3.50 a week) in April 2004, to £1,625. This represents an increase of $£ 130$ a year (roughly $£ 2.50$ a week) above the already-announced increase in line with average earnings growth.

- The various thresholds in both tax credits, and the family element of the child tax credit, would all be fixed in nominal terms at their April 2003 levels. ${ }^{3}$ This is in line with the forecasting assumption in Budget 2003. ${ }^{4}$

Figure 1 shows the distributional impact of the PBR announcements. The increase in the per-child element is targeted on the poorest half of families with children: the government estimates that 7.2 million children live in families that will benefit. The graph also shows, for information, the impact of freezing the thresholds and the family premium compared with an indexed base; this saved the government around £240 million in 2004-05 compared with an indexed base, but this saving had already been allowed for in the spending forecasts presented in Budget 2003. Compared with an indexed base, the combined effect of the tax credit changes due in April 2004 is to redistribute money within families with children, with 2.9 million middle- and high-income families with children losing in real terms from the freezes.

\footnotetext{
${ }^{3}$ The child tax credit threshold that applies to families who are not eligible for the working tax credit did rise in nominal terms, but this parameter is determined by the other parameters in the tax credits system and rose because the main working tax credit rates were indexed.

${ }^{4}$ The forecasting assumption was contained on page 203 of the 2003 Budget document:
}

\begin{abstract}
The [government's forecast for spending and receipts] has been calculated on the assumption that, each year: income tax and national insurance contribution allowances and thresholds, and the single person, couple, lone parent and disabled worker elements of the Working Tax Credit increase in line with the annual increase in the Retail Prices Index (RPI) to the September prior to the Budget; the child elements of the Child Tax Credit will rise in line with the annual increase in average earnings for the lifetime of this Parliament; VAT thresholds and gaming duty bands rise in line with the increase in the RPI to the December prior to the Budget; and air passenger duty, climate change levy, vehicle excise duty and fuel, tobacco and alcohol duties all rise in line with the projected annual increase in the RPI to the September following the Budget.
\end{abstract}

We, together with other analysts outside government, did not realise that the paragraph was supposed to imply that any parameters of the tax credits not mentioned explicitly were assumed to be frozen indefinitely until this was made explicit in a PBR press release. Hence table 1 in IFS Briefing Note 41 assumed that the thresholds were to rise in line with inflation. 
Figure 1. Distributional effects of tax credit changes in April 2004

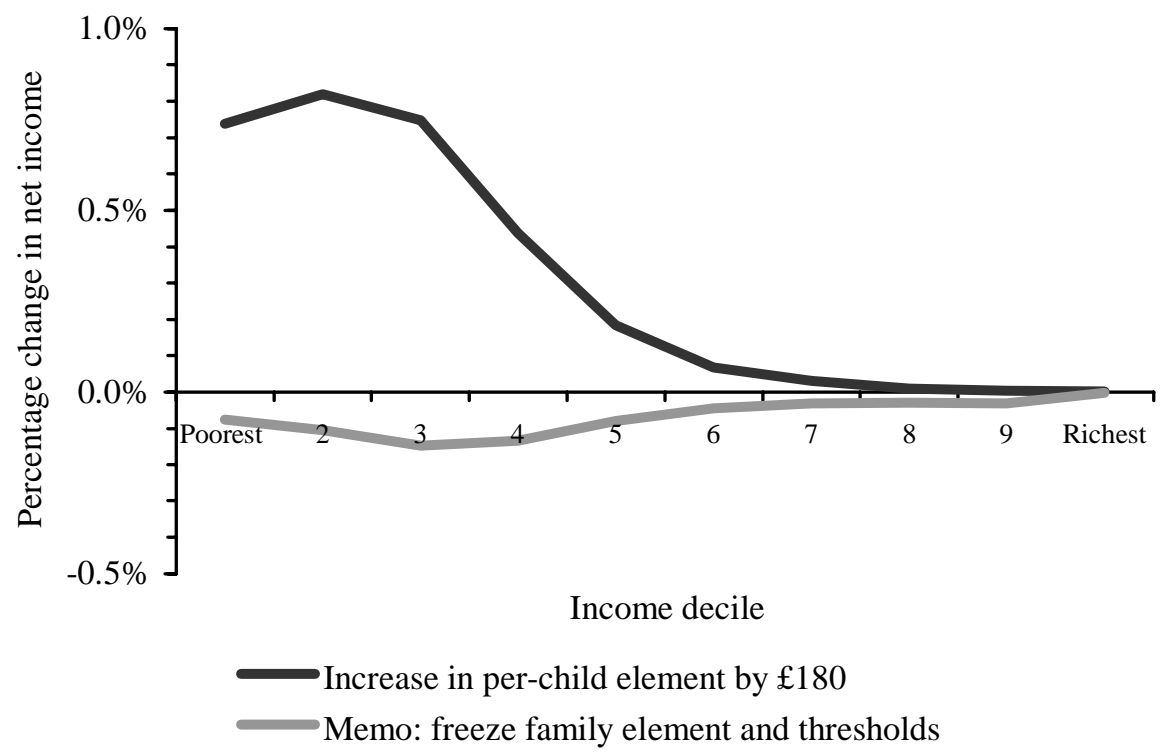

Notes: The black line shows the impact of increasing the child element of the child tax credit by $£ 180$ a year compared with a rise in line with earnings growth; the grey line shows the impact of freezing the thresholds and the family element compared with increasing them in line with inflation. Income deciles are derived by dividing all families (with and without children) into 10 equally sized groups according to income adjusted for family size using the McClements equivalence scale. Decile 1 contains the poorest tenth of the population, decile 2 the second poorest and so on, up to decile 10, which contains the richest tenth.

Source: IFS tax and benefit model, TAXBEN, based on 2001-02 Family Resources Survey.

It is also now clear that the government's assumption for future years is that the tax credit thresholds and the family premium of the child tax credit will remain at their April 2003 levels indefinitely, and that the child element will rise in line with average earnings for the rest of this Parliament. If implemented, this will continue the gradual redistribution of tax credit money towards the poorest half of families with children.

\section{The impact of the changes in PBR 2003 on child poverty}

Table 2 shows our estimates of the impact of the extra increase in the per-child element of the child tax credit announced in the PBR on child poverty. It compares this with the impact of the main policy change suggested in IFS Briefing Note 41, which concluded that an increase in the per-child rate of $£ 205$ a year, or $£ 3$ a week above the increase in line with average earnings, would be needed for the government to expect to hit its child poverty target (hereafter referred to as the 'IFS package'). The table shows that the actual PBR changes were less expensive and reduced poverty by less than the IFS package. 
Table 2. Effect of tax credit changes in April 2004 on child poverty

\begin{tabular}{|c|c|c|c|c|}
\hline $\begin{array}{l}\text { Increase in per-child } \\
\text { element of child tax } \\
\text { credit in April } 2004\end{array}$ & $\begin{array}{c}\text { Annual per-child } \\
\text { child tax credit rate, } \\
2004 \text { prices }\end{array}$ & $\begin{array}{c}\text { Number of } \\
\text { children } \\
\text { taken out of } \\
\text { poverty } \\
\text { (60\% median } \\
\text { income AHC) }\end{array}$ & $\begin{array}{c}\text { Number of } \\
\text { children } \\
\text { taken out of } \\
\text { poverty } \\
\text { (60\% median } \\
\text { income BHC) }\end{array}$ & $\begin{array}{c}\text { Cost per } \\
\text { year, } 2004 \\
\text { prices }\end{array}$ \\
\hline $\begin{array}{l}\text { 'IFS package' } \\
\text { (average earnings growth } \\
+£ 155 \text { a year) }\end{array}$ & $£ 1,650$ & 240,000 & 320,000 & $£ 1,040 \mathrm{~m}$ \\
\hline $\begin{array}{l}\text { Actual PBR package } \\
\text { (average earnings growth } \\
+£ 130 \text { a year) }\end{array}$ & $£ 1,625$ & 160,000 & 210,000 & $£ 885 \mathrm{~m}$ \\
\hline
\end{tabular}

Notes: The baseline for the cost estimates assumes that the child element of the child tax credit rises in line with earnings growth in April 2004, that all thresholds and the family premium are frozen and that other credits and allowances rise with inflation. 'Number of children taken out of poverty' is rounded to the nearest 5,000 and 'Cost per year' is rounded to the nearest $£ 5$ million, but these should not be interpreted as measures of accuracy. The poverty line was allowed to move if the reform altered median household income.

Source: Author's calculations from IFS tax and benefit model, TAXBEN, using 2001-02 Family Resources Survey.

Combining the figures in Tables 1 and 2, our central estimates are that child poverty in 2004-05 will be 3.1 million and 2.0 million, measured AHC and BHC respectively. Although the actual PBR package reduces child poverty by less than the IFS package, this difference disappears once we apply the usual rounding to the nearest 100,000 children. We conclude therefore that the government should comfortably meet its target measuring incomes $\mathrm{BHC}$, and is on course to just hit its target measuring incomes AHC.

This means that we are now slightly more optimistic than the government, which concluded that

As a result of this new investment, the Government is on track to meet or exceed its PSA target to reduce by a quarter the number of children in low-income households by 2004-05 on a BHC basis, comparable to the European child poverty indicator. The target is more challenging on an AHC basis. The nature of the target means that there are uncertainties either way. ${ }^{5}$

\footnotetext{
${ }^{5}$ Para. 5.20 of The Strength to Take the Long-Term Decisions for Britain: Seizing the Opportunities of the Global Recovery, Cm. 6042, The Stationery Office, London, 2003 (www.hm-treasury.gov.uk/pre_budget_report/prebud_pbr03/prebud_pbr03_index.cfm).
} 